\title{
Establishment of Institutional Policies for Enhancing Education Quality in Cambodian Universities
}

\author{
Sam Rany (Corresponding author) \\ School of Educational Studies, Universiti Sains Malaysia \\ PO box 11800, Penang, Malaysia \\ Tel: 60-4-175-063-234 E-mail: sr11_edu045@student.usm.my \\ Ahmad Nurulazam Md Zain \\ School of Educational Studies, Universiti Sains Malaysia \\ PO box 11800, Penang, Malaysia \\ Tel: 60-4- 653-2971 E-mail: anmz@usm.my \\ Hazri Jamil \\ School of Educational Studies, Universiti Sains Malaysia \\ PO box 11800, Penang, Malaysia \\ Tel: 60-4-653-2989 Email: hazri@usm.my
}

Received: March 30, 2012

doi:10.5430/ijhe.v1n1p112
Accepted: April 27, 2012

Published: May 15, 2012

URL: http://dx.doi.org/10.5430/ijhe.v1n1p112

This research is funded by the USM short-term research grant. It is also supported by the USM PhD Fellowship to the first author from the Institute of Graduate Studies (IPS) at the Universiti Sains Malaysia (USM), Malaysia.

The first author would like to thank Professor Dr. Roshada Hashim, Dean of the Institute of Postgraduate Studies and Associate Professor Dr. Rozinah Jamaludin, the Centre for Instructional Technology and Multimedia of the Universiti Sains Malaysia (USM) for their kind helps and encouragement.

\begin{abstract}
In the context of global and national economic development, higher education in Cambodia plays a significant role to develop human capital with technical knowledge, skills, values, and attitudes for sustainable economic growth, social development, and alleviation of poverty. When the civil war in 1998 was over, the Royal Government of Cambodia considered higher education as a top priority on the list of priorities in order to be integrated into the Association of South East Asian Nations Community by 2015 through implementing numerous mechanisms and policies to promote quality education for the students. This paper will discuss the status of national and institutional policies to promote educational quality to ensure academic success for students in a Cambodian public university. The documents and data of existing government ministries, development partners and higher education institutions will be used in the analysis of policies.
\end{abstract}

Keywords: Higher education, Institutional policies, Education quality, Academic success, Cambodian public university

\section{Introduction}

Since 1998, in the aftermath of darkness and destruction, the Royal Government of Cambodia (RGC) has initially created strategic development plans and national policies to facilitate integration into the regional and international economies and to reduce poverty among its people. Surprisingly, Cambodia became the 10th member of the Association of South East Asian Nations (ASEAN) on April 30, 1999 and the 148th member of the World Trade Organization (WTO) on October 13, 2004 respectively. Economically, Cambodia is one of the poorest nations in the world with a population of 14.7 million people with annual gross domestic product (GDP) of 802 USD per capita. Aproximately 55\% of population lives on agriculture, and $35 \%$ of the population in 2010 lives in poverty (WB, 2011). This situation, according to Jin, is a result of 
low educational quality which is one of the key factors leading to unemployment and poverty in Cambodia (Jin, 2011). Compared with neighbouring countries in the Southeast Asian region, Cambodia ranks $139^{\text {th }}$ of the 187 countries, in the area of human capital, with Singapore at 26th, Brunei at 33th, Malaysia at 61st, Thailand at 103th, Indonesia at 124th, Vietnam at 128th, Laos at 138th, and Myanmar at 149th respectively (UNDP, 2011). Cambodia has suffered the disease of corruption for many years with a ranking number $164^{\text {th }}$ out of 182 countries in the world (Guardian, 2011), and has lived in peace and security with a ranking number of $115^{\text {th }}$ out of 153 countries (IEP, 2011).

Notwithstanding some negative problems, Cambodia has considered education as one of the top priorities of the country. According to Article one of the ASEAN charter, member states have to strive to develop human resources in order to be able to compete with other members in its single market and production as well as in the common labour market and in the community of the participating nations (ASEAN, 2007). Molly pointed out that some ASEAN countries including Malaysia, Singapore, and Thailand have established their national strategies and policies to become educational exporters in order to attract their neighbouring countries' students to enroll in their own higher learning institutions (Molly, 2006). A case study of the Malaysian government reveals that it has developed its economic policies toward a knowledge-based economy through reshaping and restructuring its tertiary education to respond to globalisation of economic development (Jasvir, 2010). The Singaporean government has been making strides to become a hub for excellent education in Asia by attracting 15,0000 international students by the year 2015 (Rajaka, 2009). In addition, the Thai government has formulated its educational policies to become an education hub in the ASEAN region to recruit more international students to study in Thailand by 2016 (Rosa, 2012). Cambodia has been undertaking numerous reforms to balance the quality and quantity of education by establishing a wide range of institutions and implementing national strategies such as the Accreditation Committee of Cambodia (ACC) in 2003, the National Supreme Council of Education (NSCE) in 2005, the Rectangular Strategy for Growth, Employment, Equity and Efficiency in 2003-2012, the National Strategic Development Plan Update 2009-2013, and the Education Law (Chealy, 2009). The Prime Minister of Cambodia suggests that HEIs should set up their strategies and policies to strengthen the quality of teaching, of the curriculum, and of examinations in order to achieve recognition at regional and international levels. He also recognised that current governmental policies strive to foster the quality of education while at the same time trying to assure a balance of quality and quantity (Sen, $2011)$.

This paper will discuss and analyze institutional policies in Cambodian public universities, and will focus on the existing academic support services and non-academic support services in current Cambodian public universities that can meet the needs of students for their academic achievement and effectiveness. Therefore, this paper will examine the recent development of policy within higher education institutions in Cambodia.

\section{Recent development of policy in higher education institutions in Cambodia}

Due to the development of higher education within the global and regional contexts, Cambodia has been paying attention to its national policies in order to strengthen its educational system since 1994. First, consultative meetings between government and development partners were conducted to find out possible recommendations to reform Cambodian higher educational institutions. Remarkably, there were two significant changes since the Government implemented the privatization policies in 1997. First, the government has allowed the private sector to be involved in tertiary education. Second, the government has authorized Public HEIs (Higher Educational Institutions) to enroll non-scholarship students on a tuition fee paying basis in addition to Government scholarships which are competitively selected by the Ministry of Education, Youth, and Sports (Pit, 2004) on the basis of the grade 12 examination results. As a result, the Norton University (NU), the first private university, was established to provide educational services with affordable tuition fees together with other public universities in 1997. Presently, there are 91 Cambodian higher education institutions, comprised of 34 public and 57 private universities, in 19 provinces and in Phnom Penh, the capital. Not surprisingly, the expansion of higher education institutions is reflected in the growth of the number of enrollments. According to a report of the Ministry of Education, Youth and Sport, the total annual registration rate has increased dramatically more than four times from 57,828 to 246,069 between 2003 and 2012, with approximately 91 percent of students paying fees in the public and private HEIs. In particular, in the academic year 2011-2012, there were 1006 doctorate students, 14,127 master students, 207,666 undergraduate students, and 23,123 associate students (MoEYS, 2012). However, the rapid growth of HEIs and their enrolments has lead to the realisation of the need to confront both the low quality of education, and at the same time, the fact that the large number of educated graduates may not be equally matched with market demands (Chealy, 2009). To resolve these matters, a number of national and institutional policies and regulations have been adopted by the Cambodian parliament and government. Hence, this study will discuss the existing national policies, legal frameworks, and institutions for enhancing education quality in Cambodia.

Table1: Comparison table of student statistics from academic year 2003-2012 


\section{Existing national policies, legal frameworks, and institutions for enhancing education quality}

Presently, the Royal Government of Cambodia is striving to establish many policies and regulations to promote education quality for academic success in HEIs. There are obvious institutional policies associated with academic success and education quality. In existence are two fundamental legal instruments that determine the government's commitment to these educational policies.

First, article 65 of the Cambodian constitution stipulates that, "the state shall protect and upgrade a citizen's rights to quality education at all levels and shall take necessary steps for quality education to reach all citizens. The state shall respect physical education and sports for the welfare of all Khmer citizens. In addition, the state shall establish a comprehensive and standardized educational system through the country that shall guarantee the principles of educational freedom and quality to ensure that all citizens have equal opportunity to earn a living (RGC, 1993, admended 1999)".

Second, government strategy on the Rectangular Strategy for Growth, Employment, Equity and Efficiency in Cambodia, rectangle 4 stated that, "the Royal Government will continue to strengthen its partnerships with the private sector and the national and international community to enhance and improve the quality of education services, both in vocational and technical training and in higher education, consistent with international standards and the development needs of the nation (Sen, 2004)". Next section will highlight relevant institutions, educational policies, and regulations that are linked with institutional policies for academic success.

Figure 1: Organizational chart of existing national policies, legal frameworks, and institutions for enhancing education quality in Cambodian universities

\section{1 National policies on education}

\subsection{Educational Strategic Plan 2006-2013 (Education for All)}

There are two stages of implantation of the Education Strategic Plan from 2006 to 2013. The first stage is the Education Strategic Plan (ESP) 2006-2009, which includes the main purposes for the success of the plan. In order to achieve the goals outlined in the plan, the government has introduced the following policies in this strategic plan including increased access and equity of enrollment opportunity to realize the Royal Government of Cambodia's pro-poor policy. These strategic plans include:

(1) Implement the quality assurance and improvement at both institutional and system levels,

(2) Strengthen institutional management and development ESP 2006-2009 strategies, and

(3) Implement all the above through the Department of Higher Education of the Ministry of Education which has significant roles to implement these plans in order to meet the needs of the rapid higher education expansion (MoEYS, 2010 ).

The second stage is the Education Strategic Plan (ESP) 2009-2013, which is established to ensure linkages between education policies and strategies within the development and action programs. In this stage, the Ministry of Education continues to provide the highest priority to equitable access with education quality, in particular, to basic education in order to attain goals of the National Education for All (EFA) Plan by 2015. Furthermore, it gives greater chances to expanding early childhood education, non-formal education, technical and vocational training and opportunities to access secondary education and post-secondary education by establishing good relationship with development partners, private sectors, non-governmental organizations, communities and parents. This strategic plan also has goals to strengthen the implementation of the Education Law, the teachers' code of ethics, and good governance. In conclusion, the key components of the educational strategic plans 2006-2013 include the equitable access of students to education, the development of educational staff capacity, educational quality and assurance, and encouragement for decentralization (autonomy policy).

\subsubsection{The Master plan for research in the education sector 2011-2015}

The Master Plan for Research in the Education sector which supports the seven strategies of the Policy on Research Development in the Education Sector was approved by the Ministerial Meeting on March 14, 2011, and is guaranteed in articles 18 and 28 of the Cambodian Education Law. This master plan has been technically and financially supported by the World Bank's Higher Education Quality and Capacity Improvement Project (HEQCIP), and has mainly focused on three significant purposes to increase the number of articles published by Cambodian academicians in national and international academic journals. These projects are included:

1. To increase the number of national and international research conferences held in Cambodia.

2. To increase the number of national and international research conferences attended by academic staff and 
3. To increase the ratio of permanent to part-time or contracted academic staff (RGC, 2011).

The Master Plan also describes strategies and training programs that will facilitate research development in higher education and enhance the research capacity of academic staff and institutions. Furthermore, it highlights the need for the Cambodian public and private higher education institutions to cooperate with international education institutions to develop research and academic exchange programs that promote the educational quality of graduates for participating in the social and economic development of the country, particularly those that respond to job market demands. In short, these policies will help stimulate Cambodian educational and economic development to conform to the second stage of the Rectangular Strategy of the Royal Government of Cambodia. In addition, higher education's needs for a new legal framework to provide the foundation for high quality of education are also recognized regionally and internationally.

\subsection{Legal frameworks to support tertiary education quality in Cambodia}

Cambodia's parliament and government have passed many new laws and regulations to support educational policies for facilitating the functioning of HEIs, improving tertiary educational quality, and strengthening quality assurance. These legal frameworks included the Sub-Decree on Creating and Administering of Higher and Technical Education Institutions of 1992, the Royal Code on promulgating the Law on the Establishment of the Ministry of Education, Youth and Sport in 1996, and the Sub-Decree on Criteria of University Establishment in 2002. Other regulations are passed by the various legislative and executive institutions such as the Royal Decree on the Accreditation of Higher Education in 2003, the Resolution on the Credit Exchange System and the Implementation of Curricula in the Credit System and Credit Transfer in 2004, the Royal Degree on Promulgating the Law on Education in 2007, and the Sub Degree on PhD Training Program in 2010. Besides providing legal frameworks, some institutions actively participate in enhancing the educational quality of the current Cambodian educational system. Therefore, this paper will investigate educational institutions that support the enhancement of education quality in Cambodia.

\subsection{Educational institutions for enhancing educational quality}

There are three prominent institutions that actively participate in helping the government to implement the national educational policies and strategies and to strengthen the educational quality in Cambodian higher education institutions. These institutions are the Accreditation Committee of Cambodia, the Supreme National Council of Education, and the Directorate Department of Higher Education.

\subsubsection{The Accreditation Committee of Cambodia (ACC)}

The Royal Government of Cambodia (RGC) with development partners including the World Bank (WB), The Asian Development Bank (ADB), the United States Agency for International Development (USAID) and other donors have approved the establishment of the Accreditation Committee of Cambodia (ACC), an independent institution supervised by the Council of Ministers. However, it has been functioning as an external but official quality assurance body to evaluate the educational quality of all HEIs throughout the country. According to article 2 of the Sub-Decree on Organization and Functioning of the General Secretary of the Accreditation Committee of Cambodia, the ACC has seven vital missions which determine accreditation policy and measures to assure academic quality for all HEIs in the Kingdom of Cambodia:

a) Determining the accreditation status of HEIs

b) Approving curriculum for the foundation course for first-year university students in HEIs

c) Maintaining records of institutional and program evaluation involved with quality assurance accreditation

d) Making evaluations on the basis of visits to the HEIs

e) Cooperating with other national and international institutions involved with quality assurance and accreditation, and

f) Securing proper participation of stakeholders concerned with the outcomes of each academic institution that applies for accreditation, concerned ministries and professional associations, and

g) Making broad announcement to the public of the results of the ACC findings in relation to its task of accreditation (RGC, 2003b).

Furthermore, in order to ensure the quality of HEIs, the ACC has implemented institutional accreditation by examining nine minimum quality assurance standards of an HEI, namely its:

1. Mission

2. Governing structure

3. Management and planning 
4. Academic program

5. Academic staff

6. Student and student services

7. Learning service

8. Physical plants, financial plan and management and

9. Dissemination of information

In addition, after receiving a license from the Royal Government of Cambodia to operate its institution, each HEI is subjected to an evaluation of its management system, academic quality, and curricula in order to obtain the accreditation certificate. Only Cambodian HEIs accredited by the ACC, have the right to award bachelor, master and Ph.D. degrees in accordance with article 2 of Royal Decree on the Accreditation of Education Quality in Higher Education (RGC, 2003a). In short, this institution has significant roles to facilitate alignment of HEIs performance to meet the high educational quality standard requirements.

\subsubsection{The Supreme National Council of Education (SNCE)}

Presently, the Supreme National Council of Education (SNCE), directly supervised by the Cabinet of the Prime Minister, is in existence to support the Cambodian Educational Law. This institution has three main tasks:

1. Promote educational quality including proposing long-term educational policies and strategies in response to social and economic development needs of the government.

2. Evaluate work in the areas of education, technical and professional training and their adherence to the policy of the government

3. Mobilize a range of resources for the purpose of education (RGC, 2007)

This council has the highest authority over the Ministry of Education, Youth and Sport (MoEYS) and the Accreditation Committee of Cambodia (ACC). Remarkably, the members of the National Supreme Council of Education are appointed from among high ranking officials who have experience in education, politics, the economy, the sciences, technology and culture. The ministries and committees in charge of education and the accreditation of institutions are the Secretariat of the National Supreme Council of Education. Therefore, this council is a crucial mechanism to achieve the goal of educational quality.

\subsubsection{The Directorate Department of Higher Education (DDHE)}

The Directorate of Higher Education in Cambodia, unlike in other ASEAN countries, is structured under the Ministry of Education, Youth, and Sports (MoEYS). It has two main departments: the Department of Higher Education and the Department of Science Research. The Department of Higher Education, which employs 64 staff, is managed by a director who is supported by four deputy directors in charge of five offices: namely, the Academic Coordination Office, the Statistical Information Office, the Policy Office, the Inspection Office, and the Administration office. This Department has three key roles in developing policy and strategy for the higher education sector:

1)Providing licenses to HEIs for their operations

2)Assisting HEIs to develop academic curricula and management instruments needed to meet accreditation standards

3)Improving the quality and efficiency of higher education nationwide

The Department of Science Research is established to facilitate the educational functioning of HEIs at master's and PhD degree levels, and to improve the quality of learning-teaching and research at postgraduate levels through updating teaching methodologies and curriculum development, research and innovation, and publication. In short, this department has a fundamental role to assist the government ministries to implement their policies and strategies in order to promote Cambodian tertiary educational quality.

\section{Institutional policies for enhancing educational quality in the campus environments}

After the end of the civil war in 1998, the Royal Government of Cambodia and her national and international development partners have cooperated to establish various educational policies, projects, legal frameworks, institutions, regulations to support and ensure the education quality of Cambodian higher educational institutions. Strengthening education equality is introduced in the fourth rectangle of the government's Second Stage of Rectangular Strategy (2008-2013) for Growth, Employment, Equity and Efficiency which refers to capacity building and human resource development, p. 20 (Sen, 2004) . 
However, quality and quantity are controversial problems in Cambodia's current educational system because of the government's limited finances and people's poverty. Most poor students move from their hometowns in remote areas of the provinces to pursue their higher education at Phnom Penh, the capital. During their studies, they face many problems such as limited accommodation, lack of financial support, few scholarships, and lack of study materials.

To resolve these problems, the government has founded new universities in four different provinces such as Chea Sim University of Kamchaymear (former Maharishi Vedic University in 1991) in Prey Veng Province, Svay Rieng University (2006) in Svay Rieng Province, Mean Chey University (2007) in Banteay Meanchey province, and Battambang University (2007) in Battambang Province. In this context, Cambodia needs to increase the quality and quantity of human resource capital to compete with her neighbouring countries in ASEAN community by 2015 . Based on the literature, the government has actively taken the lead on institutional policies through providing financial support or allocations for academic activities such as research and innovations, national policies, legal frameworks, and regulations. It also has important roles to facilitate the institutional functions and their academic supported service environment. In addition, institutions need to have a high commitment to provide excellent support services for facilitating students' academic success and education quality. Institutional commitment refers to "the willingness to invest resources and provide the incentives and rewards needed to enhance student success, p.99" (Tinto, 2005).

In this paper, there are two kinds of institutional policies that can be significant factors to support students' education quality progress, and these are academic and non- academic services in this present context. In this paper, academic support services consist of academic foundation studies, foreign languages, library services and other facilities. Non-academic services refer to financial support, scholarships, and accommodation.

Figure 2: Organizational chart of the institutional policies for enhancing educational quality in the campus environments

\section{Academic support services}

Cambodian public higher educational institutions have been operating to provide appropriate academic support services in accordance with the national and regional standards including the minimum standards for Cambodian Accreditation of Higher Education Institutions and the ASEAN Network Quality criteria. There are nine minimum standards to promote quality education and academic success. Introduced in the third standard is the academic program, in the fifth standard student and student services, and in the sixth standard learning services (RGC, 2003a). Academic programs are course curricula designed to ensure and enhance the quality of education in the institutions, and they must comply with national policies, the institutional mission, social needs, the employment market, and students' needs. Student and student services are defined as academic and non academic services that contribute to the enhancement of educational quality and the student's development of knowledge, competence, and professional skills. Support services include admission services, tuition fees and scholarship services, counselling services, accommodation services, food services, first aid services, security services, and other services. Access to libraries, computer, laboratories, experimental rooms, research stations, the Internet, textbooks, journals, research papers, and so on are considered as learning services as these facilities facilitate students' learning experiences in order to attain their academic success. In the second criteria about teaching and learning of the ASEAN University Network Quality-Assurance, academic support services also include course curriculum, academic staff, student assessment, learning process, environment, health and safety standards and learning resources (ASEAN, 2004).

Hence, Cambodian public universities are effectively implementing some minimum educational quality standards to provide excellent academic and non academic support services for Cambodian students to achieve their academic development and effectiveness. At the time of writing of this paper, the Cambodian public universities are providing academic support services such as academic foundation studies, English language, library services and other facilities to support the learning environment of Cambodian students.

\subsection{Academic foundation studies}

To upgrade and strengthen the general foundation of knowledge of high school students to succeed at the tertiary level, the Royal Government of Cambodia, through the Accreditation Committee of Cambodia, has introduced foundation study programs into Cambodian HEIs in order to promote the education quality of students. Generally, Cambodian HEIs establish their own independent academic foundation departments which are accredited by the Accreditation Committee of Cambodia. These departments offer foundation studies to first year students in the undergraduate program in the academic year 2005-2006 (ACC, 2005). Thereafter, the ACC has been accrediting undergraduate and postgraduate curricula. In order to obtain a bachelor's degree, freshman students have to successfully complete a one year foundation studies program. After that, they are awarded with a foundation study certificate of achievement in all subjects in the foundation study curriculum. With this certificate, students have the right to enrol in the second year of the undergraduate 
program in the same higher education institution or in another accredited higher education institutions anywhere in the country. Currently, 38 Cambodian universities' academic foundation programs have been fully accredited by the Accreditation Committee of Cambodia (ACC, 2008).

According to article 30 of the Royal Degree on the Accreditation of Education Quality in Higher Education, academic foundation curriculums are required to introduce four compulsory disciplines: Arts and Humanities, Mathematics, Natural Science and Computer Science, Social Science, and Foreign Languages respectively (RGC, 2003a). The Discipline of Arts and Humanities includes subjects such as Literature, History, Philosophy, Fine Art, Musicology, Archaeology, Religious Studies, Khmer Studies, and other courses approved by the ACC. The discipline of Mathematics, Natural Science, and Computer Science includes subjects such as Mathematics, Chemistry, Biology, Physics, Geometry, Environmental Studies, Applied Computer, Computer Science, and other courses approved by the ACC. The discipline of Social Science includes subjects such as Political Science, Public Administration, Sociology, Anthropology, Psychology, Economics, Geography, Demography, and other courses approved by the ACC. The Discipline of Foreign Languages includes the languages of English, French, and other languages. In this foundation study program, students must complete common courses and orientation courses required by the foundation department of HEIs. For instance, the Royal University of Phnom Penh, the oldest and most prestigious university in Cambodia, offers 40 credits or 600 hours for foundation studies. If students want to achieve a bachelor's degree in Science majoring in Mathematics at the RUPP, they are required to study compulsory courses in English 1 and 2, Khmer Literature, Khmer Culture and Civilization, General Mathematics, General Chemistry and Physics, Using Library Resources and Demography, Statistics, Computer Applications, General Geography, General Algebra 1 and 2, and General Analysis 1 and 2 (RUPP, 2012f).

Similarly, the Royal University of Law and Economics, one of ASEAN Network University members, provides 36 credits or 540 hours in its academic foundation curriculum. For example, Law students have to study 12 courses including Basic Law, Computer, Culture, Foreign Languages (English, French, and Japanese), Geography, History, Institutional Law, Statistics, Political Science, and Legal French (RULE, 2012a). However, the Institute of Technology of Cambodia which specializes in engineering provides 70 credits or 3150 hours in a two-year program of foundation studies. In conclusion, foundation studies are very important to broaden Cambodian students' basic knowledge and to achieve success in their undergraduate program.

\subsection{Academic English Support}

Academic English Support Services are stipulated in standard number six of the ACC's minimum standards to promote the education quality and students' academic success. It requires that all HEIs offer English training services with highly qualified teachers and modern language learning facilities such as audio language labs and English software programs (ACC, 2009). From a Cambodian historical perspective, higher education institutions use many foreign languages in instruction due to the influence of political ideologies and to the technical and financial support of donor countries. During the 1980s, most universities used the instructional languages of Russian and Vietnamese, for example, the Soviet Friendship Higher Technical Institute used Russian as the instructional medium with Soviet professors.

After the collapse of the Soviet Union, France has donated about US\$ 7 million through the Francophone University Agency (Agence Universitaire de la Francophonie) to support this institute. Eventually, the French language became the medium of instruction, and France renamed this institute to become the Institute of Technology of Cambodia (Insitut de Techonologies du Cambodge-ITC) on September 10, 1993. However, at that time, most students protested against using French because they wanted to continue their instruction in Russian, Khmer, or English. Although presently Cambodia is one of 56 French speaking state members in the International Organization of the Francophonie (IOF, 2012 ), Cambodian students are no longer required to use the French language in their tertiary level of studies (Clayton, 2006). There are many controversial problems about language choices between English and French in the current Cambodian higher education institutions.

According to Clayton (2006), most Cambodian academicians and administrators, who worked at RULE, RUPP, NUM, and UHS, have taken every opportunity to convert their French instruction to English; Cambodian students have preferred to study English rather than other languages. For instance, when RUPP and RULE have amended their language policies and allowed students to select their own foreign language options, 80 \% of RUPP's students chose English and $84 \%$ of RULE's students selected English. On the other hand, after Cambodia became member state of ASEAN in 1999, English has significantly influenced Cambodian students on their language of choice. English is an official and working language of ASEAN according to article 34 ASEAN's charter (ASEAN, 2007), whereas the Cambodian constitution in article 5 stated that Cambodian official language and script are Khmer (RGC, 1993, admended 1999).

However, Cambodian scholars have always considered English language skills as most important for students' learning, communication, employment, and scholarship opportunities abroad, and it is the first and leading foreign language in the 
country. The Cambodian Ministry of Education started to introduce an English curriculum into secondary schools and high schools throughout country in 2000. Because of limited English proficiency among Cambodian students and lecturers, most Cambodian public universities have used only Khmer as the official instructional language. According to Louise Ahens (2000) interviewed in (Clayton, 2006), Cambodian students need to know English because nearly all textbooks are in English. She emphasized that "Cambodia can't afford to develop new textbooks every few year like major academic publishers in the United States do. Thus, if students cannot read English, they simply can't function in higher education." She also suggested that Cambodian students who want to pursue their postgraduate degrees in the region and in English speaking countries must have English proficiency because English is the language of international education at nearly all universities in ASEAN as well as in Europe and North America.

Generally, Cambodian HEIs provide three years or six semesters of English language training to undergraduate students. Cambodian public universities are not setting test scores of English proficiency tests like TOEFL or IELTS in their admission requirements. For example, since 1997, the RUPP has established its institutional policy to offer English services through the English Language Support Unit (ELSU). It provides English language training to students in all faculty departments except foreign language departments at the Institute of Foreign Languages. RUPP' students are required to complete six semesters of compulsory English courses in order to receive a degree from the university. Before starting classes in first year, students are required to take an English placement test to evaluate their English proficiency. After that, RUPP provides classes for students in various levels depending on their English placement test results, and they have to attend at least six hours of English classes per week. The ELSU of RUPP has been providing English basic courses and elective courses including general English (from elementary to upper- intermediate levels), English for Employment, Academic Writing, Southeast Asian Studies, Introduction to Research Skills, English Teaching Methodology, and TOEFL Test Preparation (RUPP, 2012d). As a result, after students successfully complete six semesters, they are able to attain at least basic academic research skills in their field of research. Moreover, if students had an upper-intermediate level of English proficiency in their first year or second year, they will be able to study specific subjects and advance concepts for writing their research report or final thesis (RUPP, 2012e). Beside these courses, the ELSU also provides English services during Summer School to improve English proficiency by offering enrichment courses for all RUPP students and students from other universities in Phnom Penh. These summer courses cover the five macro language skills of Listening, Speaking, Reading, Writing, and Grammar (RUPP, 2012c).

In addition, the Royal University of Law and Economics provides seven semesters of compulsory English training in its law and economics undergraduate curriculum. These English programs are provided in conjunction with the English Language Institute (USA) based at the Royal University of Law and Economics (RULE, 2012b). Because of effective policies of English training services, leading universities including the Royal University of Phnom Penh, The Royal University of Law and Economics, and the National University of Management have been sending their students to study at English speaking universities in Australia, New Zealand, United States, Europe, and some countries in Asia. For example, 480 Cambodian students have received the Australian Development Scholarships (ADS) to pursue their postgraduate studies in Australia since 1994 (AKP, 2012), and more than one hundred students have been awarded Fulbright Scholarships (FS) to do their postgraduate studies at universities in the United States (FAAC, 2012). In short, Cambodian public universities have provided appropriate academic English services to support students' learning experiences, academic excellence, and education quality.

\subsection{Library Services}

Library services and resources are considered as one of the minimum standards needed to ensure education quality and to facilitate students' learning process to help them succeed (ACC, 2009). Moreover, library services have a positive impact on students' academic success including learning, persistence, retention, faculty research productivity, and student job success. In particular, universities need new teaching technologies and new electronic information sources such as databases, up-to-date textbooks, periodicals, journals, advanced multimedia resources, high-speed Internet access, liquid crystal display projectors (LCD projectors), computer labs, visual and audio equipment so on to facilitate student learning p. 348 (Heyneman, 2001).

Presently, access to Cambodian universities' library resources is limited because of shortages of governmental financial support. However, university students can access textbooks and printing materials for their academic research and learning process. Universities strive to encourage students to use library services effectively. For example, RUPP offers a library orientation program, a compulsory course on using library resources to all first year students. This course attempts to improve students' research and information seeking skills in the library, teaching them how to use reference books including encyclopaedias, atlases, and dictionaries as well as how to search for documents using technologies such as the Internet, email, CD-Rom, Video, and microfiche (RUPP, 2012g). The Hun Sen Library of the Royal University of Phnom 
Penh, the largest library in Cambodia, officially opened on January 7, 1997 under the financial support of the Cambodian government and donors from European countries, the United States, and Japan. The library currently has a floor area of 1600 square meters with seating for 200 users and has approximately 55, 000 textbooks, of which $62 \%$ are in English, $22 \%$ in Khmer, $15 \%$ in French, with others in Japanese, Vietnamese, Chinese, and Thai. The library provides services such as Internet access, word processing and printing, photocopying services, online public Access Catalogue (OPAC), circulation services (loan and general collection), and library orientation workshop services (RUPP, 2012h).

In addition, the Royal University of Law and Economics has two separated libraries for the faculties of law and economics where each library has 495 square meters of space. There are approximately 22,788 general textbooks and 23,788 legal and economic textbooks. Remarkably, at least 550 students per day (RULE, 2010) access the university's library. Beside universities' libraries, most students use the National Library of Cambodia, the biggest library in the country, to research in their academic activities; this library has approximately 10 3,635 textbooks and 23,000 volumes of books and journals (Post, 2012) .

\section{Non Academic support services}

\subsection{Financial services and Scholarship}

Currently, there are 173, 264 undergraduate students (25,045 government scholarship students), 20,719 associate students (3079 government scholarship students), and 55, 149 foundation students (7512 government scholarship students) in Cambodian HEIs (MoEYS, 2011). Both scholarship and non- scholarship students face financial difficulties because they need to spend a lot on living expenses such as food, accommodation, tuition fees, and study materials at the universities of the capital. Presently according to census information in 2010, approximately $80.5 \%$ of the Cambodian population lives in rural areas, $55 \%$ lives on agriculture, and 35\% lives in poverty (NIS, 2008; WB, 2011). About $80 \%$ of provincial and rural students pursue their higher learning in universities at Phnom Penh, the capital of Cambodia. Therefore, the Royal Government of Cambodia and higher education institutions annually increase the number of scholarships and establish appropriate policies to set affordable tuition fees for non-scholarship students. The provisions of scholarships and financial supports are based on the following criteria:

\section{For outstanding or talented students}

2. For deserving students who are not able to afford paying fees for their higher education

3. For students who are studying in prioritized fields or specializations for society's need as determined by the Royal Government of Cambodia, and

4. Other scholarships in response to the policies of the country's leaders

These scholarship awards are based on the proportion of gender, geographic location, and ethnic groups in Cambodia (ACC, 2009; RGC, 2003a). For example, the Royal University Phnom Penh annually awards 770 scholarships to students (RUPP, 2012a) while the University Health Science awards 741 scholarships (UHS, 2012a). The Royal University Law Economics annually provides 390 scholarships included 300 government scholarships, 10 outstanding or talent student scholarships, and 50 Prime Minister's scholarships (RULE, 2010). The tuition fees of current public universities are between USD 250 and USD 1500 per year. It is cheaper when compared with other universities in the Southeast Asian countries. For instance, the RUPP categorizes its annual tuition fees into three groups:

\section{USD 250 for the Faculty of Social Science and Humanity \\ 2. USD 300 for the Faculty of Science and \\ 3. USD 450 for the bachelor's degree in Computer Science and English (RUPP, 2012b)}

The Royal University of Law and Economics sets tuition fees in the amount of USD 380 for Law and Economics undergraduate programmes. Otherwise, medical studies in the University of Health Science being the most prestigious discipline, demand the highest tuition fees in the country, i.e. USD 1400 for Medicine, Pharmacy, and Dentistry (UHS, 2012b). In Cambodia, government scholarships only cover tuition fees, so students need to rely on parents, family, and part-time employment for living expenses. According to Virak (2010), the budget allocation in higher education is not proportionate to the ratio of students sponsored between the Ministry of Education and other ministries that provide higher education services. For example, some ministries may sponsor $10 \%$ of the students, but they receive about $60 \%$ of government grants, whereas the Ministry of Education sponsors $90 \%$ of the students, but receiving only $40 \%$ of government grants for higher education expenditures.

Moreover, the number of government scholarship in Public HEIs is expanding, but the program based budget (PB) in higher education institutions is shrinking. Beside the government's existing scholarship program, World Bank (WB) and 
the Cambodian government have a five year project on Higher Education Quality and Capacity Improvement (2010-2015) to provide 1,050 "special-priority" scholarships based on pro-poor targeting and educational criteria in order to increase the retention of poor students in higher education (Virak, 2010; WB, 2012 ). This World Bank collaborative scholarship which pays between USD 60 and USD 90 depending on the location of provincial or capital universities is higher than government scholarship because it covers tuition fees and monthly allowances. In conclusion, financial support services and scholarships are very important to facilitate students to succeed in their academic activities and reach excellence.

\subsection{Accommodation}

Accommodation services are spelled out in the Minimum Standard number five for the Accreditation of Higher Education Institutions regarding student and student services. It states that HEIs have to provide good services to their students; these services include accommodation, food services, first aid, security, and other necessary services. Living environment in campuses are vital factors to retain students particularly first year students in college and university. Students who live on campus are able to persist into second year when compared to students who live off campus. (Jenniefer, 2004; Kenty, 1997). Moreover, students who stay in university accommodation or residential halls are more likely to be actively involved in all university experiences and activities because they have enough times to interact with their peers, administrators, and faculty members (Astin, 1999).

Presently, Cambodian leading public universities in the Phnom Penh do not have their own university accommodation, whereas four public provincial universities including the Chea Sim University of Kamchaymear, Svay Rieng University, Mean Chey University, and Battambang University have their own campus housing offered freely to prioritized female students and other students whose families live far away from university campuses. Actually, most students are challenged with problems to find suitable accommodation during their studies at universities in Phnom Penh. Some students have to stay with relatives and friends, and others have to rent accommodation near their university campus. Fortunately, most male students have a chance to find free accommodations in pagodas because their families are so poor that they cannot afford rental rooms.

As a result, the Royal Government of Cambodia has constructed a six-storey building as a dormitory near the campus of the Royal University of Phnom Penh. This accommodation is for students from poor families, remote provinces, and for females who study at the universities in Phnom Penh (Saoyuth, 2010). The government will finance some national budgets to expand university dormitories to meet the need of rapid enrolment rates of students in Phnom Penh. It also has many projects to build colleges and universities in other provinces throughout the country in order to reduce the number of students coming to Phnom Penh to continue their education. In short, accommodations are very important to facilitate the education quality in tertiary levels.

\section{Discussion}

Based upon the finding of this research, Cambodian government and higher educational institutions have strived to establish numerous policies, strategies, regulations, institutions and academic support services for promoting the education quality. To achieve this goal, the government has implemented three main national strategies including the Rectangular Strategy for Growth, Employment, Equity and Efficiency, the National Strategic Development Plan Update 2009-2013, and the Educational Strategic Plan (Education for All) 2006-2013. Especially, the Privatization Policy has permitted private sectors to invest in tertiary education. As a result, the numbers of Higher Education Institutions have been dramatically expanded to more than three times from 28 to 91 between 1997 and 2012. Beside these strategies, the government has cooperated with development partners and country donors to create various projects and plans for the enhancement of higher education quality including the Master Plan for Research in Education Sector 2011-2015, the Higher Education Quality and Capacity Improvement 2010-2015, and the Development Grants for Cambodian Higher Education Institutions. Moreover, three prominent institutions have been established to facilitate these strategies and policies and to assure the education quality that comprised of the Accreditation Committee of Cambodia, the Supreme National Council of Education, and the Directorate Department of Higher Education. Remarkably, each higher education has strived to improve the quality of curriculums and extra-curricular activities, research projects, and teaching methodologies as well as to provide some academic supported services for the special needs of students. As a result, educational qualities of undergraduate programmes in Cambodia have been recognized by some world- class universities through accepting Cambodian students to enrol in their postgraduate programmes; particularly, in the development scholarship programmes of friendship countries.

However, there are several crucial and missing problems need to be urgently addressed that could impact on the effectiveness of the educational policy implementation and the quality of education in Cambodia HEIs. The first problem is the constraints on higher education financing, which is limited by the government's budget. The overall education expenditure accounted for only 1.6 percent of Cambodia' gross domestic product and public higher education expenditure 
was only 0.05 percent of GDP (WB, 2012). Because of these shortages of annual budgets, Cambodian higher education institutions cannot implement their institutional policies to equip modern and adequate facilities to effectively support the academic and non academic services for student academic successes such as libraries, workshop, accommodation, laboratories, and classrooms. Corruption and non transparency of public expenditures in HEIs are also considered as serious problems. The government has not yet create regulations or policies on public financial management within public and private higher education institutions. They should be required to broadcast their annual financial statements for the public. Controversially, some universities are actively involved in selling diplomas, and bribes are paid for degrees, academic assignments, and thesis writing (Shane, 2012).

The second problem is lacking of admission requirements. Most Cambodian higher education institutions are not setting the specific admission policies and criterions to recruit qualified students to attend in their institutions, and they mainly depend on the results of higher school examinations. Consequently, they have competed in attracting the numbers of enrolments for the purpose of their commercial benefits. Especially, English or other foreign languages are not required by most public universities as entrance requirements.

Third problem is lacking human resources, teaching qualities, and research capacity. There are few full time academicians who hold PhD's degree in Cambodian universities because of insufficient salaries and incentives; especially, educational experts and policy makers who have qualified experiences and skills to restore Cambodian educational system to meet the requirements of world class universities. On the other hands, the Accreditation Committee of Cambodia has not enough qualified assessors and experts to evaluate the training activities and to assure the education quality of higher education institutions. In addition, Cambodia is still not policy on academic professional ranking so that it is not encouraging people to work in academic careers. Similarly, most universities have problems with research capacity. For instance, a study of five prestigious Cambodian universities had found that only 6 percent of university lecturers hold PhD's degree and about 85 percent have never published any academic papers (Chen, 2007).

The forth problem is academic relevance. Cambodian government has not yet policy on curriculum and extra-curricular activities to linkage with the labour markets. Presently, the high rates of unemployment among the university graduates are due to their lack of professional skills to respond with the demands of labour markets. For example, most of Cambodian higher education institutions are providing most disciplines in business studies, economics, and IT, whereas current Cambodian labour markets are demanding in natural science, engineering, mathematics, agriculture, and health (Noch, 2009). The last problem is autonomy and academic freedom within the public universities. The government has policies to provide HEIs a legal status as quasi-government institutions or public administration institutions (PAIs), but the implementation is inactive because of political motivations and pressures. Currently, there are twelve specialized ministries and agencies to supervise and to provide higher education services in Cambodia (Sam, 2012). As a result, political parties and parent ministries have rights to interference in making decisions of higher education institutions as well as in nominating high academic ranking officers based on political interests rather than academic qualifications. Furthermore, academic freedom is so strict in Cambodian democratic society; for example, the freedom of expression related to politics, human rights, democracy, corruption, transparency, good governance, and social justice debate are prohibited by government within the HEIs.

To sum up, Cambodian government and higher educational institutions have high commitment to set up many policies for promoting the quality of education, but these policy implementations have faced some controversial problems because of financial shortages, time constraints, inadequate human resources, and autonomy and academic freedom. Therefore, during 14 years of peace and political stability, the government has achieved in numerous national policies and strategies for developing human capital, socio- economy, and alleviation of poverty.

\section{Conclusion and recommendation}

The purpose of this paper is to explore the institutional policies that address academic and non-academic support services provided by the Cambodia public universities to support the needs of students to enhance their academic success and education quality. Hence, this paper provided a review of current literature, policy documents and discussion about education quality in Cambodia as well as the academic and non-academic support services that are provided in current public universities.

Based in the discussion on various aspects in previous section, the following recommendations are made to contribute in enhancing education quality at national and institutional levels. For the national level, the government should pay more attention on HEIs which expand public financial support for their academic functioning, and increase sufficient salaries and incentives; the government should effectively audit their expenditures with transparency and accountability. The government should put more effort to encourage higher education for reforming their institutional policies such as admission requirements, curriculum and extra-curricular activities, teaching methodologies, research methods, and 
practical skills that are demanded by labour markets. The government should allocate some national budgets to support unpopular courses and programmes for the profits of country. The government should provide adequate training courses related to educational planning and management, strategic management, and higher education administration for universities' staffs and faculty members. The government should transform public higher education institutions to be the PAIs in order to make their own decisions in academic and non academic activities. Finally, the government should provide academic freedom for students, professors, and lecturers in accordance with Cambodian constitution both inside and outside university campuses.

For the institutional level, HEIs should pay more attention to offer adequate academic and non academic support services for their students including foreign language services, library services, internet and computer services, advisory and counselling services, accommodation services, canteen services, health and security services, transportation services, and financial support and scholarship services. HEIs should provide only subjects or programmes which match with their competencies, academic background, and resources for the student academic success and education quality. HIEs should make more social events and academic activities to maintain good relationship between students and faculty members. HEIs should regularly develop professional competencies of academicians and staffs to assure the quality of education and support services.

Ultimately, the discussion arrived at here suggests that a provision of significant academic and non-academic support services will enable Cambodia public universities to support the actual and urgent needs of students and thereby contribute to their academic excellence and education quality in order to integrate its educational system into the ASEAN community by 2015 .

\section{References}

ACC. (2005). Annual Report on Activities of General Secretary of the Accreditation Committee of Cambodia in 2005. [Online] Available: http://www.acc.gov.kh/acc/annual_report.html (March 3, 2012)

ACC. (2008). List of fully accredited universities in Cambodia in 2008. Phnom Penh: The Accreditation Committee of Cambodia.

ACC. (2009). Minimum Standards for Accredition of Higher Education Institutions. Phnom Penh: Accredition Committee of Cambodia (ACC). [Online] Available: http://www.acc.gov.kh/index. php? option $=$ com_content\&view $=$ article\&id $=46 \&$ Itemid $=53($ March 3, 2012)

AKP. (2012). Australia to Provide Scholarships to 50 Cambodian Students for 2012. The Agence Kampuchea Press. [Online] Available: http://www.akp.gov.kh/?p=16150 (March 2, 2012)

ASEAN. (2004). ASEAN University Network Quality-Assurance Guideline. Bangkok, ASEAN University Network.

ASEAN. (2007). The Charter of the Association of South East Asia Nations. [Online] Available: http://www.aseansec.org/21069.pdf (December 1, 2011)

Astin, A. (1999). Student Involvement: A Developmental Theory for Higher Education. Journal of College Student Development, 40(5), 518-529. [Online] Available: http://www.middlesex. mass.edu /tutoringservices/downloads/astininv.pdf (December 4, 2011)

Chealy, C. (2009). Higher Education in Cambodia. In Y. Hirosato, \& Y. Kitamura (eds.) (Ed.), The Political Economy of Educational Reforms and Capacity Development in Southeast Asia (pp. 153-165): Springer 2009, (Chapter 9).

Chen, C., Sok, P., \& Sok, K. (2007). Benchmarking Potential Factors Leading to Educational Quality in Cambodia. Quality Assurance in Education, 15(2), 128-148. http://www.doi: 10.1108/ 09684880710748901

Clayton, T. (2006). The Assistance Context for Language Choice: Education (Cambodia). Language Choice in a Nation Under Transition: English Language Spread in Cambodia. USA: Springers, (Chapter 5).

FAAC. (2012). The Fulbright Alumni Association of Cambodia. [Online] Available: http://cambodia.usembassy.gov/faac.html (March 4, 2012)

Guardian. (2011). Corruption index 2011 from Transparency International: find out how countries compare. [Online] Available: http://www.guardian.co.uk/news/datablog/2011/dec/01/corruption-index -2011-transparency-international? $\mathrm{fb}=$ native ( December 17, 2011)

Heyneman, S. (2001). The growing international commercial market for educational goods and services. International Journal of Educational Development, 21(4), 345-359. http://dx.doi.org/10.1016/S0738-0593(00)00056-0 
IEP. (2011). Global Peace Index. Australia: Institute for Economics and Peace. [Online] Available: http://www.visionofhumanity.org/gpi-data/\#/2011/scor (February 26, 2012)

IOF. (2012). State Members of Francophonie (Countries Using French Language) in 2012. International Organization de Francophonie. [Online] Available: http://www.francophonie. org/ English. html (February 29, 2012)

Jasvir, K., Jan, S., \& Susan, M. (2010). The impact of economic policy on reshaping higher education in Malaysia. Research and Development in Higher Education, 33, 585-595. [Online] Available: http://ww.herdsa.org.au/wp-content/.../HERDSA2010_Singh_J.pdf(February 26, 2012)

Jenniefer, C., \& Upgraft, M. (2004). The Key to First-Year Student Persistence. In John, N., Upcraft, L., \& Betsy, B. (Ed.), Challenging and Supporting the First Year Student: A Handbook for improving the First Year of College United States Jossey Bass

Jin, H. (2011). Poverty in Cambodia. [Online] Available: http://13jinhyo. files.wordpress. com/ 2011/ 05/hyowon-poverty1.pdf (November 28, 2011)

Kenty, J. (1997). Knowing your students better: A key to involving first-year students. The CRLT Occasional Paper 9 , page 1-7.

MoEYS. (2010 ). Educational Strategic Plan 2010-2013. Phnom Penh The Ministry of Education, Youth, and Sport (MoEYS)

MoEYS. (2012). Summary Report of Congress on the Education, Youth and Sport in the Academic Year 2011-2012 . Phnom Penh, Cambodia.

Molly, L., \& Stephen, H. (2006). Higher Education in South-East Asia : An Overview Higher Education in South-East Asia. Bangkok, Thailand: the UNESCO Asia and Pacific Regional Bureau for Education. [Online] Available: http://www.unesdoc.unesco.org/images/0014/001465/146541e.pdf

NIS. (2008). General Population Census of Cambodia in 2008. Phnom Penh: National Institute of Statistics of the Ministry of Planing, Cambodia. [Online] Available: http://www.stat. go.jp/english/ info/meetings/cambodia/pdf/pre_rep1.pdf (November 28, 2011)

Noch, C. (2009). Higher Education and Unemployment of the Educated in Cambodia. (Unpublished Master thesis). The International Institute for Educational Planning (IIEP), UNICEF, Paris.

Pit, C., \& David, F. (2004). Cambodian Higher Education: Mixed Visions. In P. G. Altbach \& T. Umakoshi (Ed.), Asian Universities: Historical Perspectives and Contemporary Challenges (pp. 333-362 ). Baltimore and London: The Johns Hopkins University Press, (Chapter 13).

Post, S. (2010, August, 18). A look at the Kingdom's best libraries. The Phnom Penh Post. [Online] Available: http://www.phnompenhpost.com/index.php/2010081841314/LIFT/a-look-at-the-kingdoms-best-libraries.html (March 3, 2012)

Rajaka, B., \& Peggy, B. (2009). Global student mobility: moving towards brain exchange. In Rajika, B., \& Shepherd, L. (Ed.), Higher Education on the move: new developments in global mobility (page 1-14 ). New York: Institute of International education, (Chapter1).

RGC. (1993, admended 1999). The Constitution of Cambodia. Phnom Penh: The Constitutional Council of Cambodia.

RGC. (2003a). Royal Degree No. NS/RKT/303/129 dated on March 31, 2003 on the Accreditation of Education Quality in Higher Education Phnom Penh: The Council of Ministers, Cambodia.

RGC. (2003b). Sub degree No. 46 GNKR. BK dated June 12, 2003 on Organizing and Functioning of General Secretary of Accreditation Committee of Cambodia. Phnom Penh: The Council of Ministers.

RGC. (2007). Royal Degree No. NS/RKM/1207/032 dated December 8, 2007 concerning the Education Law. Phnom Penh: The Office of Council of Ministers, Cambodia.

RGC. (2011). Master Plan for Research Development in the Education Sector 2011-2015. The Ministry of Education, Youth, and [Online] Aports. Available: http://moeys.gov.kh/en/policies-and-strategies/73-policies/172-master-plan-for-research-development-in-the-education-s ector-2011-2015.html (January 18, 2012 )

Rosa, B., \& Renze, K. (2012). International student recruitment: policies and developments in selected countries. Netherlands: Nuffic (Netherlands organisation for international cooperation in higher education). [Online] Available: http://www.nuffic.nl/international.../international-student-recruitment .pdf (January 19, 2012 ) 
RULE. (2010). Summary Report on Management and Training Situation at the Royal University of Law and Economics. Phnom Penh: The Royal University of Law and Economics

RULE. (2012a). Foundation Curriculum of the Royal University of Law and Economics. http://www.rule.edu.kh/Foundation-Year.htm (February 28, 2012)

RULE. (2012b). Undergraduate Curriculum of Economics at the University of Law and Economics. [Online] Available: http://www.rule.edu.kh/Bac_Eco.htm (March 3, 2012)

RUPP. (2012a). Admission Requirements and Scholarship Awarded Numbers. [Online] Available: http://www.rupp.edu.kh/studentlife/admition_requirements.php (March 3, 2012)

RUPP. (2012b). Course Fees of the Royal University of Phnom Penh. [Online] Available: http://www. rupp.edu.kh/studentlife/course_fees.php (March 3, 2012)

RUPP. (2012c). English Language Summer School Program at RUPP. [Online] Available: http:// www.rupp.edu.kh/center/elsu/summer_program/summer_program.php (March 1, 2012)

RUPP. (2012d). English Language Support Unit: Curriculum and Course Description. [Online] Available:http://www.rupp.edu.kh/center/elsu/curriculum_course_description/curriculum_course_des.php (March 1, 2012)

RUPP. (2012e). English Support Unit in the RUPP. [Online] Available: http://www. rupp. edu. kh/ center/elsu/introduction/introduction.php (March 1, 2012)

RUPP. (2012f). Foundation Curriculum of the Royal University of Phnom Penh. [Online] Available: http://www.rupp.edu.kh/foundation/curriculum/curriculum.php (February 28, 2012)

RUPP. (2012g). RUPP Course Description of Using Library Resources.[Online] Available: http://www.rupp.edu.kh/foundation/course_description/course_description2.php

RUPP. (2012h). RUPP Library Service in the Royal University of Phnom Penh. http://www.rupp.edu.kh/center/ls/lbservice/service.php (March 2, 2012)

Sam, R., Ahmad, N., \& Hazril, J. (2012). Cambodia's Higher Education Development in Historical Perspectives (1863-2012). International Journal of Learning and Development 2(2), 224-141.

http://dx.doi.org/10.5296/ijld.v2i2.1670

Saoyuth, D. (2010, September 15). Home away from home. The Phnom Penh Post. [Online] Available: http://www.phnompenhpost.com/index.php/2010091542055/LIFT/home-away-from-home.html (March 3, 2012)

Shane, W. (2012, January 3). For many, it's a matter of degree. The Phnom Penh Post. [Online] Avialable: $\mathrm{http} / / / \mathrm{khmerization}$.blogspot.com/2012/01/for-many-its-matter-of-degrees.html (March 4, 2012)

Sen, H. (2004). The Rectangular Strategy for Growth, Employment, Equity and Efficiency in Cambodia. Phnom Penh: The Office of the Council of Ministers. [Online] Available: http://www.embassyofcambodia.org.nz/government.htm (March 10, 2012)

Sen, H. (2011 ). Keynote Address at the Conferment of Certificate and Degree to Graduates of the University of Human Resources on August 11, 2011, Phnom Penh, Cambodia. [Online] Available: http://www.cnv.org.kh/ (March 10, 2012)

Tinto, V. (2005). Student Retention: What Next? Paper presented at the 2005 National Conference on Student Recruitment, Marketing, and Retention, Washington, D.C. [Online] Available: http://www.heacademy.ac.uk/assets/documents/resources/database/VincentTinto_research_and_practice_of_student_ret ention.pdf (March 10, 2012)

UHS. (2012a). Scholarship Students in the Foundation Department. [Online] Available: http://www.univ-sante.edu.kh/index.php/en/faculties--schools/foundation-year (March 3, 2012)

UHS. (2012b). University of Health Science: Tuition Fees in 2012. [Online] Available: http://www.univ-sante.edu.kh/images/files/tarifs.pdf (March 3, 2012)

UNDP. (2011). Human Capital Implications of Future Economic Growth in Cambodia: Elements of a Suggested Roadmap. Phnom Penh, Cambodia: United Nation Development Program and Supreme National Economic Council. [Online]Available: $\quad$ http://www.un.org.kh/index.php? $\quad$ option $=\quad$ com_ jdown loads\&Itemid $=65 \&$ view $=$ viewdownload\&catid $=4 \& \mathrm{cid}=84($ March 1,2012$)$ 
Virak, Y. (2010). The Quality Assurance in Higher Education in South East Asian Countries: The Case of Cambodia Paper presented at the The Regional Seminar on Quality Assurance in Higher Education in Southeast Asia Countries, Bangkok, Thailand. [Online] Available: http://www.rihed. seameo.org/ mambo/qa2009/cambodia_report.pdf (March 1, 2012)

WB. (2011). GDP per capita (current US\$) in Cambodia. [Online] Available: http://www.data. worldbank.org/indicator/NY.GDP.PCAP.CD (November 28, 2011)

WB. (2012 ). Higher Education Quality and Capacity Improvement Project for University Scholarship. [Online] Available: http://www-wds.worldbank.org/external/default/ main?page $\mathrm{PK}=64193027 \&$ piPK $=$ $64187937 \&$ theSitePK $=523679 \&$ menuPK $=64187510 \&$ searchMenuPK $=64187283 \&$ siteName $=$ WDS\&entityID $=0003349$ 55_20100720050542 (March 2, 2012)

WB.(2012). Putting Higher Education to Work: Skills and Research for Growth in East Asia (pp.113-116). Washington, DC.: The International Bank for Reconstruction and Development.

Table 1. Comparison table of student statistics from academic year 2003-2012

\begin{tabular}{|l|c|c|c|c|c|c|}
\hline \multirow{2}{*}{ Degree } & \multicolumn{2}{c|}{ 2003-2004 } & \multicolumn{2}{c|}{ 2010-2011 } & \multicolumn{2}{c|}{ 2011-2012 } \\
\cline { 2 - 7 } & Total & Female & Total & Female & Total & Female \\
\hline Associate Degree & 11,517 & 2879 & 20,719 & 6,526 & 2,3123 & 7631 \\
\hline Bachelor Degree & 44,855 & 13,905 & 173,264 & 70,954 & 20,7666 & 8,3066 \\
\hline Master Degree & 1448 & 174 & 12,887 & 2,343 & 14,274 & 2855 \\
\hline Doctorates & 8 & 2 & 981 & 55 & 1006 & 60 \\
\hline Grand Total & \multicolumn{3}{|c|}{57,828} & \multicolumn{2}{c|}{207,851} & \multicolumn{2}{c|}{246,069} \\
\hline
\end{tabular}

Sources: MoEYS, Department of Higher Education and Department of Scientific Research, 2012

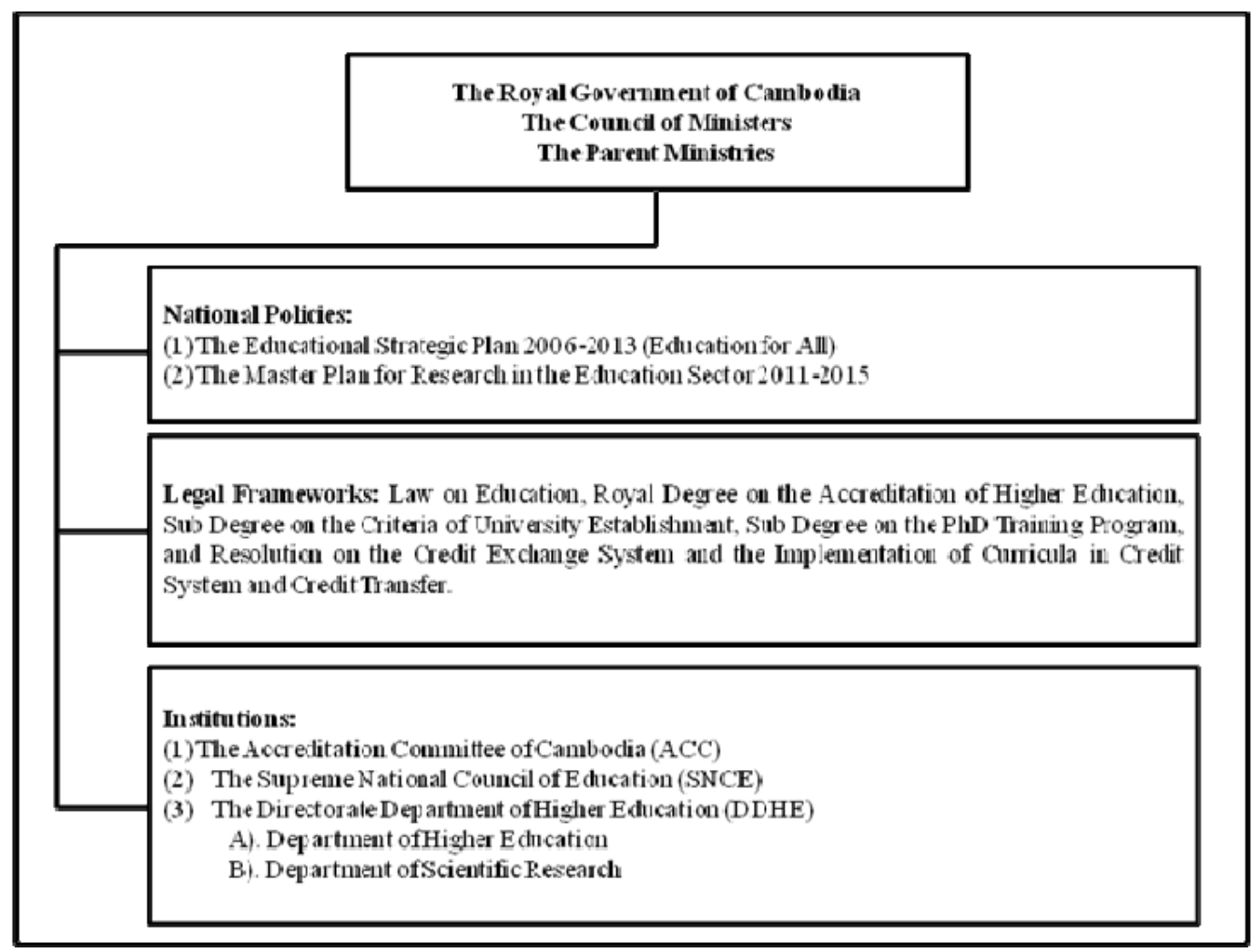

Figure 1. Organizational chart of existing national policies, legal frameworks, and institutions for enhancing education quality in Cambodian universities 


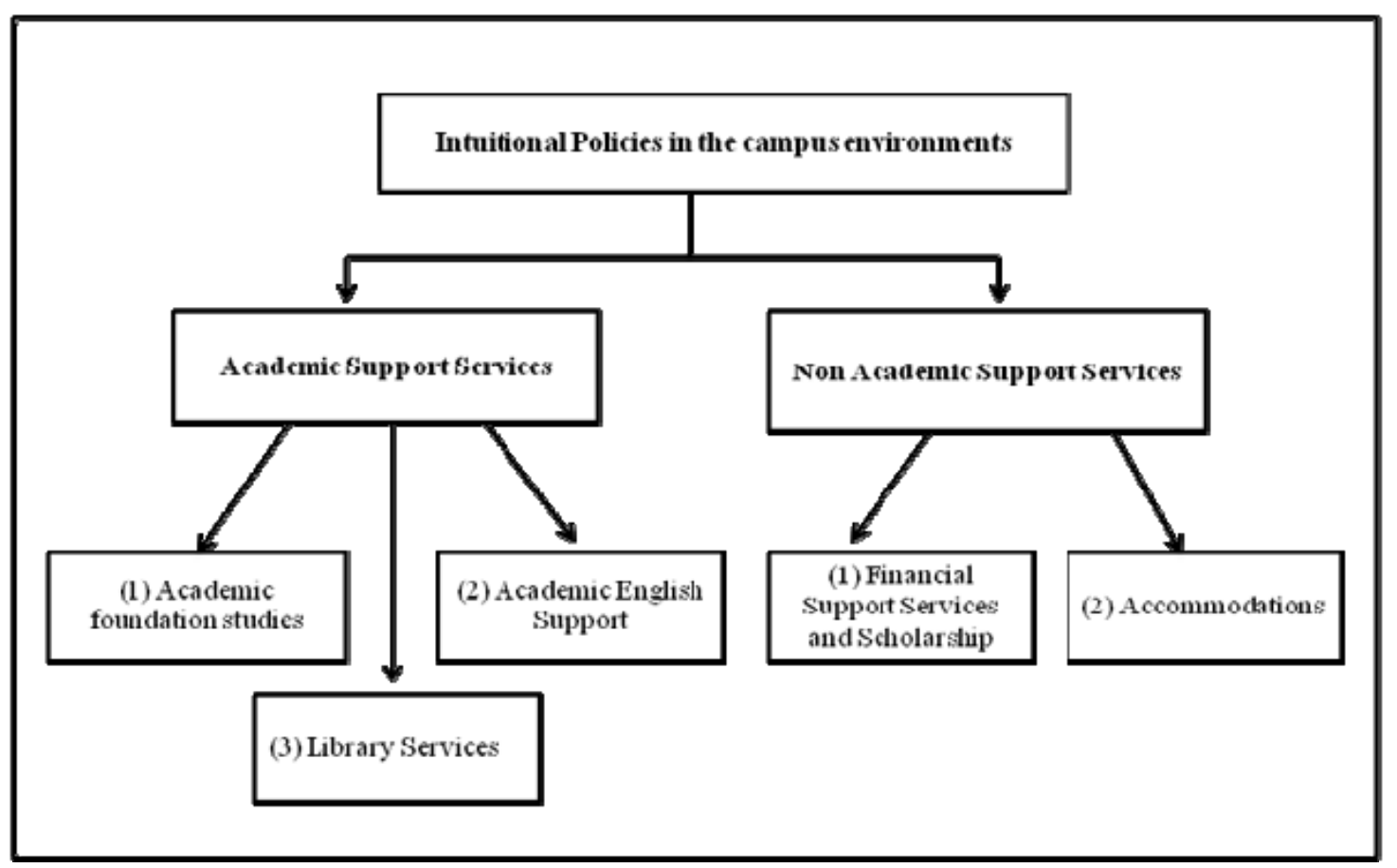

Figure 2. Organizational chart of the institutional policies for enhancing educational quality in the campus environments 